\title{
Kandidatens trøst - pasientens mareritt?
}

\begin{abstract}
Sammendrag
Bakgrunn. Karpunksjoner er en nødvendig del av moderne medisin, men kunnskapen om karenes nære relasjon til nerver synes å være mangelfull.
\end{abstract}

Materiale og metode. Vi refererer to pasienthistorier som viser mulige konsekvenser av kanyleringer av vena cephalica og arteria radialis.

Resultater. Begge pasienter utviklet symptomer og kliniske og nevrofysiologiske funn som tydet på en skade av radialisnerven. Den ene pasienten vil mest sannsynlig ikke utvikle en kronisk nevropatisk smerte, mens hos den andre kan den tilsvarende skaden av nervus radialis føre til kronisk og invalidiserende smerte.

Fortolkning. Vi fraråder distale del av v. cephalica («kandidatens trøst») som førstevalg ved kanylering og for trening av uerfarne studenter. Venen bør forbeholdes pasienter der man mangler alternative veneveier og ved akuttsituasjoner der det er behov for rask væskeinfusjon eller blodtransfusjon.

\section{Gunnvald Kvarstein}

gunnvald.kvarstein@medisin.uio.no

Anestesi- og intensivklinikken

Ellen Jørum

Klinisk nevrofysiologisk seksjon

Nevrologisk avdeling

Oslo universitetssykehus, Rikshospitalet

Postboks 4950 Nydalen

0424 Oslo

De overflatiske grener av nervus radialis og distale del av vena cephalica og arteria radialis ligger i anatomisk nærhet til hverandre. V. cephalica krysser de overflatiske grenene av n. radialis like proksimalt for karporadialleddet (fig 1) mens a. radialis følger tett inntil nervegrenene. Med kun noen få millimetre mellom blodkar og nervegren er nervefibrene spesielt utsatt for stikkskader.

\section{Materiale og metode}

Vi refererer her fra egen praksis to pasienthistorier som viser potensielt alvorlige kon- sekvenser av kanyleringer av v. cephalica og a. radialis.

\section{Pasient 1}

Før et elektivt kirurgisk inngrep fikk en 45 år gammel kvinne anlagt kanyle $i$ v. cephalica like proksimalt for venstre håndledd («kandidatens trøst»). Under innføring av nålen rapporterte hun akutt innsettende smerter strålende ut $i$ venstre langfinger. Neste dag var hun øm i venstre langfinger og anga nedsatt ekstensjonskraft i og sensibilitetsutfall langs dorsalsiden av venstre 2. og 3. finger. Trykk over innstikksstedet utløste ilende fornemmelse utover radialsiden av hånden. I løpet av en måned forsvant den pågående, spontane smerten, men sensibilitetsendringer var fortsatt til stede.

Klinisk nevrologisk og nevrofysiologisk undersøkelse avdekket støtliknende og ilende smerte ved lett trykk over den overflatiske grenen av n. radialis. Man fant nedsatt følesans for lett berøring $i$ et lite hudparti ved basis av venstre langfinger og $i$ et kronestort område ved basis av venstre pekefinger. Hun hadde ingen berøringsallodyni (smerte ved normalt ikke-smertefullt stimulus) men en trykkhyperalgesi løkt smerte ved trykk) ved innstikkstedet for kanylen, som beskrevet over.

\section{Pasient 2}

En 47 år gammel mann ble i forbindelse med hjertekateterisering påført sterk smerte under kanylering av høyre a. radialis. I de første to ukene etter kanyleringen var smerten begrenset til innstikkstedet $5,5 \mathrm{~cm}$ proksimalt for håndleddsbøyefuren, Deretter utviklet han sterk smerte langs radialsiden av underarmen og utover håndbaken samtidig som hånden hovnet opp.

Ved klinisk nevrologisk undersøkelse fem måneder etter skaden fant vi tegn til autonom dysfunksjon og nedsatt sensibilitet, men ingen allodyni for lett berøring $i$ det radialisinnerverte hudområdet. Han hadde derimot en lokal allodyni for lett berøring på underarmen og en hyperalgesi for trykk i et noe større område.

Etter ett år hadde hevelsen gått vesentlig tilbake, men den kunne fortsatt variere $i$ intensitet. Hånden fremsto blank og misfarget (blå/rød) og vekslet mellom å være varmere og kaldere enn den venstre. Smerten vedvarte med en intensitet 4-9 på en numerisk skala fra $0-1010=$ ingen smerte og $10=$ maksimalt tenkelig smerte) og omfattet nå alle fingrene. Behandling med pregabalin reduserte smertens intensitet til 0-6 lgjennomsnittlig 4). Pasienten anga generelt nedsatt kraft $i$ hånden og nedsatt sensibilitet $i$ det radialisinnerverte hudområdet.

\section{Nevrografi}

Nevrografi av overekstremitetene ble utført med Dantec Counterpoint og med måling av motorisk distal latenstid, amplitude og ledningshastighet til $\mathrm{n}$. medianus og $\mathrm{n}$. ulnaris samt måling av sensorisk latenstid og ledningshastighet til de samme nervene. N. radialis' overflatiske gren ble evaluert med måling av sensorisk svaramplitude og ledningshastighet bilateralt.

Det var hos begge pasienter normale forhold for de motoriske og sensoriske fibrene i n. medianus og n. ulnaris i venstre overekstremitet, og i n. radialis var det sidelike normale forhold for de sensoriske fibrene.

\section{Tynnfiberfunksjon}

Spesifikk evaluering av tynnfiberfunksjon (C- og A $\delta$-fibre) ble utført ved hjelp av termotest (Somedic, Sverige) og med måling av deteksjonsterskler for varme, kulde, varmesmerte og kuldesmerte (1). Målingene ble utført i innervasjonsområdet for $\mathrm{n}$. radialis' overflatiske gren bilateralt i spatium interosseum primum.

For pasient 1 viste tynnfiberundersøkelsen normale og sidelike deteksjonsterskler for varme og kulde bilateralt, men lett nedsatt sensibilitet for kulde. Deteksjonsterskelen for kulde var på $29,9^{\circ} \mathrm{C}$ på venstre side, mot $30,9^{\circ} \mathrm{C}$ på høyre side, varmesmerteterskelen på den affiserte venstre siden var $47,9^{\circ} \mathrm{C}$, mot $44,2^{\circ} \mathrm{C} \mathrm{i}$ den friske hånden. I tillegg ble det påvist kuldeallodyni på venstre side med kuldesmerteterskel $18,1^{\circ} \mathrm{C}$, mot normalt under $10^{\circ} \mathrm{C}$ på høyre side.

For pasient 2 forelå det sterkt nedsatt sensibilitet for både varme og kulde på høyre

\section{Hovedbudskap}

- Ved kanylering av vener og arterier er det risiko for samtidig skade av nervestrukturer

- Distale del av v. cephalica («kandidatens trøst») bør ikke være førstevalg ved kanylering

- Sykehusavdelinger bør etablere gode rutiner som kan redusere risikoen for nerveskade 
side sammenliknet med venstre, med varmedeteksjonsterskel på $45,2{ }^{\circ} \mathrm{C}$ på høyre side, mot normalt $33,9^{\circ} \mathrm{C}$ på venstre side og kuldedeteksjonsterskel på $18,9^{\circ} \mathrm{C}$ på høyre side, mot $30,8^{\circ} \mathrm{C}$ på venstre side. Varmesmerte var opphevet på høyre side, dvs. over $50^{\circ} \mathrm{C}$, mens den var normal på venstre side $\left(38,9^{\circ} \mathrm{C}\right)$. Vi fant ingen kuldeallodyni.

\section{Tolking av funn}

For pasient 1 tydet funnene ved termotesten på affeksjon av de afferente tynnfibrene, hovedsaklig av de afferente $\mathrm{C}$-fibrene some er ansvarlig for varmesmerte, men kanskje også en lett affeksjon av de afferente A $\delta$-fibrene som er ansvarlig for kuldedeteksjon. I tillegg ble det påvist en overfølsomhet for kulde, hvilket kunne tyde på en skade av visse tynnfibre selv om mekanismene for kuldeallodyni ennå ikke er fullt avklart.

For pasient 2 var skaden av tynnfibrene mer uttalt med affeksjon av både de varmemedierende og varmesmertemedierende afferente $\mathrm{C}$ fibrene og de kuldemedierende $\mathrm{A} \delta$-fibrene. Til tross for normale funn ved nevrografi hadde han på klinisk grunnlag og ut fra termotest en lesjon av n. radialis. Smertebildet, med samtidig tegn til autonom dysfunksjon, gjorde at han fylte kriteriene for komplekst regionalt smertesyndrom av type 2 , tidligere kalt causalgi.

\section{Diskusjon}

De omtalte pasientene var våkne under stikkprosedyren og reagerte momentant med smerte. Typisk er lokal smerte som eventuelt stråler utover nervens forsyningsområde. Det er grunn til å minne om at anesteserte pasienter ikke vil være i stand til å reagere.

Begge pasienter utviklet symptomer samt kliniske og nevrofysiologiske funn som tydet på skade av radialisnerven. Det kliniske bildet kunne gi inntrykk av skade på tykke, myeliniserte nervefibre med nedsatt sensibilitet for lett berøring. Affeksjonen var i disse tilfellene ikke av en slik grad at det påvirket nevrografiresultatet. Det er også grunn til å minne om at nevrografi er en grov undersøkelse, der man kun evaluerer funksjonen til de tykke myeliniserte nervefibre. Spesifikke undersøkelser (f.eks. termotest) er nødvendig for å påvise skade på de tynne nervefibrene.

\section{Konsekvenser av nerveskade}

Stikk i nervestrukturer kan føre til langvarig nedsatt sansefunksjon og alvorlige smertetilstander. Så langt vi vet, foreligger det ingen prevalenstall for nerveskade etter kanylering av perifere vener eller arterier. En undersøkelse viste forbigående nerveskade hos $1,7 \%$ av pasientene som for kirurgi hadde fått nervepleksusblokade (2). Det er grunn til å forvente underrapportering. Risikoen for skade har vist seg å øke ved injeksjon av lokalbedøvelse direkte inn i nerven $(3,4)$. Nerveskader generelt er en relativt vanlig årsak til perifer nevropatisk smerte. Få studier er publisert, men insidensen er 2,5-5,0\% $(5,6)$ og opptil $22,9 \%(7)$.

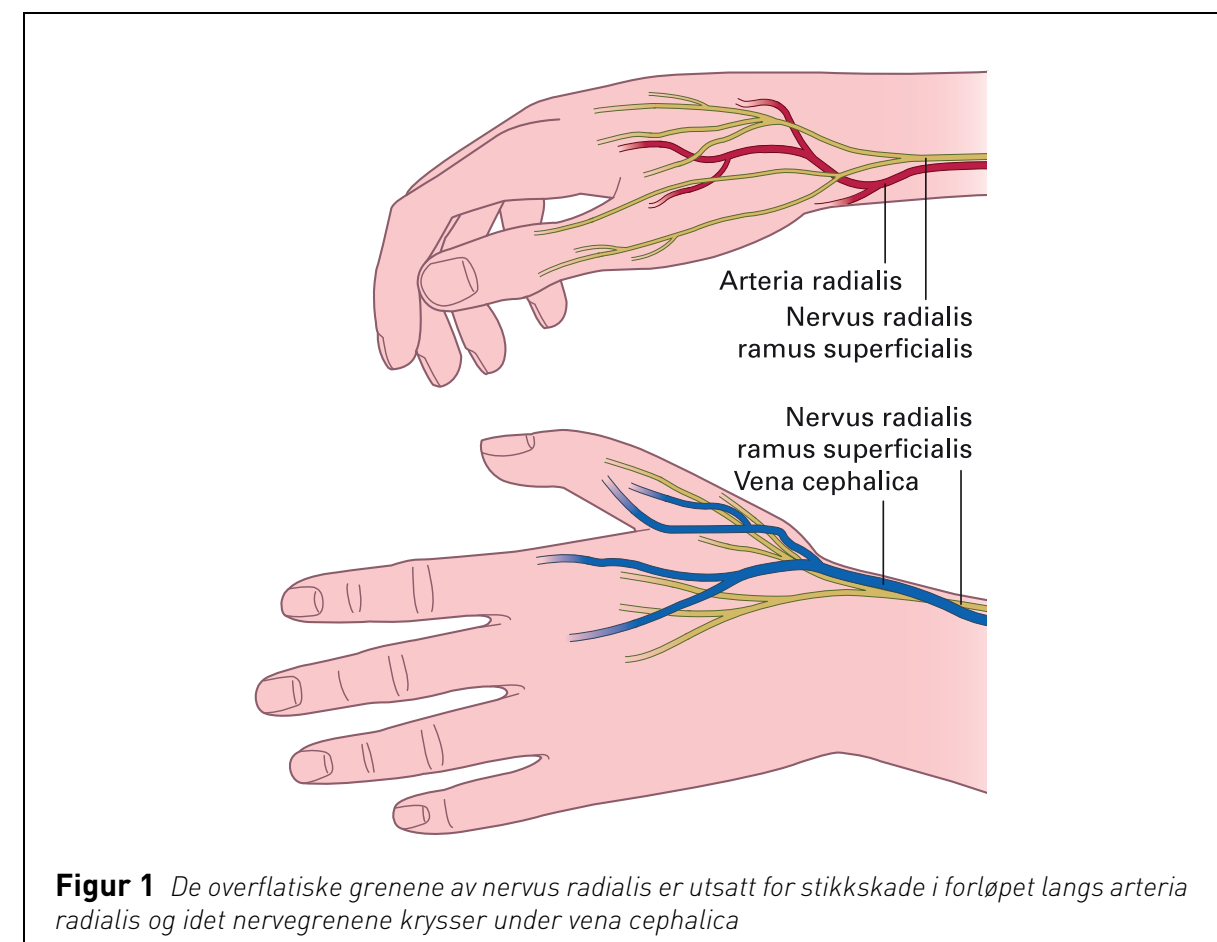

radialis og idet nervegrenene krysser under vena cephalica

Pasient 1 vil mest sannsynlig ikke utvikle kronisk nevropatisk smerte. Den spontane smerten var i tilbakegang en måned etter skaden, men hun hadde fortsatt vedvarende trykkutløst smerte. Det andre eksempelet viser imidlertid at tilsvarende skade av $\mathrm{n}$. radialis, utløst av kanyleinnstikk, kan gi opphav til kronisk og invalidiserende smerte.

Man antar at langvarig smerte etter stikk i en nerve skyldes skade av tynne umyeliniserte, nociseptive C-fibre. Det er svært sjelden at nerveskader med ren tykkfiberaffeksjon gir smerte. For å bekrefte en slik hypotese må man undersøke pasienter med og uten smerte etter nerveskade. Svært få slike studier er utført, men i en studie av pasienter med skade av n. trigeminus (8) fant forfatterne ingen forskjell $i$ tynnfiberfunksjon på affisert side mellom pasienter med og uten smerte. Likevel vil man anta at skade av nociseptive fibre er en forutsetning for utvikling av smerte (9). Hypereksitabilitet av smertefibrene (dvs. spontan fyring eller spontant oppståtte aksjonspotensialer) antas å være den vanligste årsaken til smerte etter nerveskade (10).

De metoder som man benytter klinisk for påvisning av tynnfiberutfall, har sine begrensninger og vil ikke kunne avdekke hvilken feil og skader i nervefibrene som er ansvarlig for smerten. Det gjelder både hudbiopsi med påvisning av tetthet av tynnfibre $i$ epidermis og termotest med påvisning av nedsatt funksjon til de afferente temperaturmedierende nervefibrene. I påvente av nye metoder vil det imidlertid fortsatt være behov for påvisning av tynnfiberskade med de metoder vi har tilgjengelig. For den enkelte pasient kan det være viktig å få dokumentert nerveskaden, ikke minst der vanlig nevrografi er normal.
Oppgitte interessekonflikter: Ingen

Begge pasienter har gitt samtykke til at artikkelen blir publisert.

\section{Litteratur}

1. Warncke T Stubhaug A Jørum E Ketamine, an NMDA receptor antagonist, suppresses spatial and temporal properties of burn-induced secondary hyperalgesia in man: a double-blind, crossover comparison with morphine and placebo. Pain 1997. 72: 99-106.

2. Fanelli G, Casati A, Garancini P et al. Nerve stimu lator and multiple injection technique for upper and lower limb blockade: failure rate, patient acceptance, and neurologic complications. Study Group on Regional Anesthesia. Anesth Analg 1999 88: 847-52.

3. Marchettini P, Lacerenza M, Mauri E et al. Painful peripheral neuropathies. Curr Neuropharmacol 2006: 4: 175-81.

4. Hogan QH. Pathophysiology of peripheral nerve injury during regional anesthesia. Reg Anesth Pain Med 2008; 33: 435-41

5. Sunderland S. Miscellaneous causes of nerve injury. I: Sunderland S, red. Nerve injuries and their repair. Edinburgh: Churchill-Livingstone, 1991: 197-9

6. Kline DG, Hudson AR. Pain of nerve origin. I: Kline DG. Hudson AR, red. Nerve injuries. Philadelphia, PA: Saunders, 1995: 512-23.

7. Roganovic Z, Mandic-Gajic G. Pain syndromes after missile-caused peripheral nerve lesions: part 1-clinical characteristics. Neurosurgery 2006; 59 : $1226-36$

8. Jääskelainen SK, Teerijoki-Oksa T, Forssell H. Neurophysiologic and quantitative sensory testing in the diagnosis of trigeminal neuropathy and neuropathic pain. Pain 2005; 117: 349-57.

9. Gottrup H, Nielsen J, Arendt-Nielsen L et al. The relationship between sensory thresholds and mechanical hyperalgesia in nerve injury. Pain 1998: 75: 321-9.

10. Woolf CJ, Mannion RJ. Neuropathic pain: aetiology, symptoms, mechanisms, and management. Lancet 1999; 353: 1959-64.

Manuskriptet ble mottatt 17.6. 2009 og godkjent 15.4. 2010. Medisinsk redaktør Are Brean. 